\title{
Austrian UNESCO Biosphere Reserves as model regions for regional culinary enjoyment
}

\section{Günter Köck}

Keywords: biosphere reserves, sustainable development, food products, marketing, partner networks

\section{Abstract}

In many UNESCO Biosphere Reserves (BRs), the production and marketing of regional farm produce are an essential, if not the most important, contribution to regional development. Using the example of the Austrian BRs, this article reviews the possibilities and framework conditions for the production and marketing of farm produce, and discusses culinary potential as an important component of the sustainable development of the region in national and international contexts.

\section{Introduction}

Today, protected areas such as national parks, UNESCO Biosphere Reserves (BRs) and nature parks are increasingly taking on regional economic activities and playing an important role in the economic development of the region. The production and marketing of regional farm produce are important contributions to regional development. BRs, with their multifunctional orientation as model regions for sustainable development, are particularly suitable for establishing environmentally sound land-use concepts and regional marketing structures for sustainable local products.

Like many other BRs, those in Austria face the challenge of combining biodiversity conservation with economic development in the best possible way. As agriculture still plays a central role in BRs' traditional cultural landscapes, many initiatives in recent years have focused on agriculture (Weixlbaumer \& Mose 2019). The broad spectrum of possible actions ranges from close-to-nature and site-appropriate land use, the use of environmentally friendly technologies, to the implementation of forms of tourism that are compatible with both (social or tourist) expectations and environmental concerns. Particular potential lies in the development of regional value chains, starting with the production, distribution and marketing of environmentally friendly regional products. Regional culinary products can have positive effects on several levels: for producers, they are a source of additional income; for local people, they are an essential element of food supply; for visitors, they are sought-after souvenirs. Thus, culinary products are valuable instruments for nature conservation, education and regional development (Asamer-Handler \& Handler 2019). Regional farm produce can be vehicles for making people more aware of the concept of sustainability and of the importance of biocultural diversity, while at the same time promoting the economic development of the region.

Using the four Austrian BRs as examples, this paper aims to showcase the opportunities that the regions have in terms of the production and marketing of farm produce and local specialities. The BRs' po- tential for delivering culinary enjoyment will also be discussed, with regard to how it can be used to implement the complex BR concept in a national and international context. At the same time, the relationships between producers, consumers and gastronomy businesses will be elucidated.

\section{The Austrian BRs}

With the Großes Walsertal, Salzburger Lungau \& Kärntner Nockberge, Wienerwald and Lower Mura Valley BRs, Austria currently has four model regions for sustainable development (Figure 1, Table 1). A variety of foodstuffs are made in the BRs, ranging from traditional local products that have been produced in the regions for a long time, to innovative products that use new production methods.

The description and selection of the examples presented in this article are based on an extensive literature review, enquiries made in the BRs, and informational interviews with representatives of the BRs' management and producers on site. The aim is to present the current spectrum of culinary BR products as comprehensively as possible (see also Table S1, available online).

\section{Culinary enjoyment as an opportunity for conservation of biocultural diversity and sustainable development}

The UNESCO Man and the Biosphere (MAB) Programme's BR concept is ideally suited to protecting valuable natural and cultural landscapes, which have often been influenced and shaped by man for centuries, for future generations, in a sustainable manner. In the second half of the $20^{\text {th }}$ century, the great intensification of agriculture led to excessive degradation of cultural landscapes and to a significant decrease in agrobiodiversity. At the same time, political and cultural resistance to this process of agro-industrialization developed. Sustainability experts, civil society and consumers are increasingly calling for change. The typical small-scale ecological agriculture of BRs is not only 


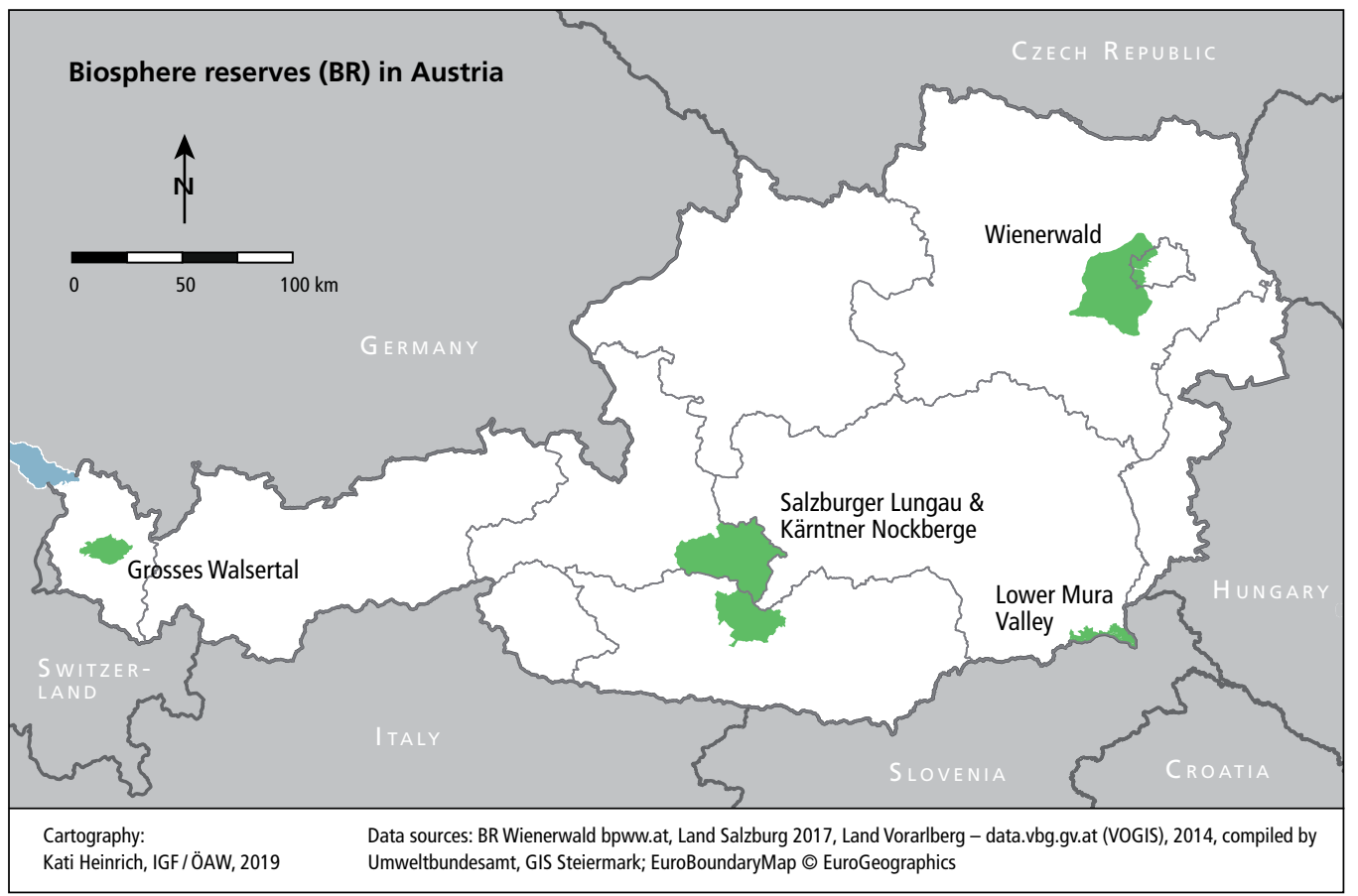

Figure 1 - BRs in Austria.

more efficient in terms of land and energy use, but also combines food security with climate protection and soil conservation. In addition, it also forms the basis for the long-term culinary enjoyment potential of a region by providing traditionally produced food, heritage varieties of fruit and vegetables, and tasty local specialities (Weixlbaumer \& Mose 2019).

In times of climate change, the protection of diverse, small-scale agricultural landscapes, associated with locally adapted, sustainable agricultural practices, as well as the promotion of local, artisanally made goods, is particulary indispensable. Preserving a high level of agrobiodiversity, which secures not only the future basis of human life but also the supply of a diverse range of high-quality foods, includes the conservation of habitats, species and intra-species diversity (IPBES 2019; BfN 2020). Several international initiatives aim to contribute to this. These include the Globally Important Agricultural Heritage Systems (GIAHS) programme of the Food and Agriculture Organisation (FAO) for the conservation of agricultural heritage, and the Interreg AlpFoodway project for the preservation of the cultural food heritage in the Alpine region (Scheurer et al. 2018; AlpFoodway 2019; FAO 2020). Such aims have now also become an international concern at the political level, as demonstrated by the declaration of the agriculture ministers of the world's biggest economies (G20) in July 2018, which promised, among other things, to promote sustainable agriculture and agri-food supply chains, and to revitalize sustainable traditional farming systems (G20 2018). Outdoor-based livestock farming, the avoidance of high nutrient loads through synthetic fertilizers, as well as voluntarily avoiding the use of synthetic pesticides, as in organic farming, are indispensable strategies in this context. They are also called for in the Farm2Fork strategy published by the European Commission in May 2020 (European Commission 2020a,b).

For BRs, it would certainly be desirable to obtain a protected geographical indication of origin for their culinary products, such as inclusion in the EU's Register of Protected Designation of Origin (PDO) or Protected Geographical Indication (PGI). PDO means that the entire production process of a product in a specific geographical area must follow a recognized, established and legally controlled procedure. For PGI, it is sufficient if at least one of the stages of production (production, processing or manufacture) has taken place in a specific region of origin, or if the product has a particular reputation or quality.

Through strict protection and control, displaying a label of legally protected geographical origin means

Table 1 - List of biosphere reserves in Austria.

\begin{tabular}{|l|l|r|r|r|}
\hline Biosphere Reserve & Federal province & Established & Size [ha] & Location \\
\hline Großes Walsertal & Vorarlberg & 2000 & 19200 & $47^{\circ} 13^{\prime} 8^{\prime \prime} \mathrm{N}, 9^{\circ} 54^{\prime} 8^{\prime \prime} \mathrm{E}$ \\
\hline Wienerwald & Vienna, Lower Austria & 2005 & 105004 & $48^{\circ} 8^{\prime} 28^{\prime \prime} \mathrm{N}, 16^{\circ} 4^{\prime} 56^{\prime \prime} \mathrm{E}$ \\
\hline Salzburger Lungau \& Kärntner Nockberge & Salzburg, Carinthia & 2012 & 148914 & $46^{\circ} 58^{\prime} 09^{\prime \prime} \mathrm{N}, 13^{\circ} 43^{\prime} 32^{\prime \prime} \mathrm{E}$ \\
\hline Lower Mura Valley (Unteres Murtal) & Styria & 2019 & 13180 & $46^{\circ} 43^{\prime} 34^{\prime \prime} \mathrm{N}, 15^{\circ} 50^{\prime} 46^{\prime \prime} \mathrm{E}$ \\
\hline
\end{tabular}


significant added value for both producers and consumers. Such labels are credited by consumers with a high degree of trust, for whom they signal a high level of quality. As a result, many consumers are prepared to pay higher prices for such products, which can naturally benefit regional value-creation (EU-IPR Helpdesk 2016; WIPO 2017).

The same applies to the two global initiatives of the Slow Food Foundation for Biodiversity, namely Ark of Taste and Presidia (Slow Food 2018). Although these do not offer legally controlled protection of origin, they do contribute to awareness-raising and strengthen short (regional) quality-oriented supply chains. By anchoring supply chains in regional ecosystems, landscapes and cultural areas, such initiatives can contribute to bio-cultural diversity, and to the preservation of region-specific production structures, skills and jobs (Ermann et al. 2018).

\section{Regional culinary enjoyment as an opportu- nity for sustainable development}

Culinary delights are an excellent vehicle for marketing local products as a quality feature of a region (Köck et al. 2013; Weixbaumer \& Mose 2019). Furthermore, the production and sale of regional culinary products contributes not only to the conservation of bio-cultural diversity, but also to the stimulation of the regional economy (Kraus 2015; Ketterer Bonnelame et al. 2019).

Locals and tourists alike value authentic, high-quality regional goods, produced in an environmentally friendly manner, that allow identification with the region. For tourists, edible souvenirs from their holiday region have a high reminder value and may inspire them to visit the place again. Studies show that, regardless of people's primary travel motives, enjoyment of local culinary specialities is important on holiday and therefore has a decisive influence on the image of a destination. According to these studies, approximately $30 \%$ of holiday expenditure is on food and beverages (Stöckl 2015, 2017). This means that the local culinary offer is seen as an important addition to the overall offer of a destination, giving a competitive advantage to regions that can offer local specialities and various culinary activities (e.g. tastings and demonstrations). The quality of the culinary experience is therefore a decisive factor in terms of visitor satisfaction and loyalty.

According to a study conducted on Austrian consumers by the University of Applied Sciences Krems, food and nutrition have become a lifestyle issue. Furthermore, regionality, seasonality and ethical correctness have become important factors influencing the decision for or against purchasing a given product (Stöckl 2015).

Many gastronomic and tourist accommodation businesses are following this trend and increasingly use regional products. Unfortunately, after initial en- thusiasm, many of these initiatives fail due to the often-limited availability of regional products. Particularly in tourist areas with large gastronomic and tourist accommodation structures, many businesses regret the small size of the available product range, as well as the shortfall in supply resulting from the small size of the producers.

If local people bought more regional products, they would make it easier for local producers to survive economically and thus enable the expansion of production and distribution structures. If there was sufficient supply and thus security of supply, the gastronomic and accommodation businesses would increasingly choose these products and thus further secure the economic success of the producers. However, gastronomic and tourist accommodation businesses, producers, tourists and consumers must all be able to demonstrate a certain degree of flexibility: not all products have to be (or can be) available at all times and in the desired quantities.

\section{Strategies to promote regional culinary en- joyment}

An active BR management could play a significant role as initiator, facilitator and information hub in the implementation of strategies for promoting regional cuisine, like the preservation of region-specific production structures and bio-cultural diversity.

\section{Partner networks}

An active BR management could certainly help as a platform and provider of ideas for local agriculture, trade and tourism. The BR management could play an important role in establishing a partner network by moderating and supporting the development of criteria for becoming partner businesses and for BR products. Eligible to become BR partners would be companies from various sectors committed to the sustainable development of the region, resource protection and the promotion of regional value chains. Good examples can be found in numerous BRs in Switzerland, Sweden and Germany, where well-functioning networks of business partners have been developed, e.g. in the Entlebuch, River Landscape Elbe and Rhön BRs (Knaus et al. 2017; Flusslandschaft Elbe 2018; Rhön 2019).

When drawing up the framework conditions in a particpative process with all stakeholders, care must be taken to ensure that ambitious but achievable goals are set. Criteria that are overambitious and/or too narrowly defined, which overstretch the capabilities of many companies and thus exclude some from the outset, are counterproductive. Of course, the involvement of organic farms is absolutely desirable and should be encouraged. However, for organic status to be a mandatory criterion is counterproductive if a significant number of farms in the area do not operate (officially) according to organic criteria. But it often happens that 
farms, especially smaller ones, do produce according to organic standards but cannot afford official organic certification and the associated requirements.

Usually, certified partner farms in a BR are entrepreneurial, are committed to sustainable regional development, and thus underline the MAB programme's claim to show exemplary ways of sustainable development in its model regions. For example, the BR managements of the German federal states of Lower Saxony, Mecklenburg-Vorpommern, Brandenburg and Sachsen-Anhalt, and the Kommunale Arbeitsgemeinschaft zur Zusammenarbeit im Elbetal (KAG) (the municipal working group for cooperation in the Elbe Valley) have created a standardized conceptual framework for interested businesses in the River Landscape Elbe BR. The framework is in line with the guidelines for partnerships as represented by the umbrella organization for all large-scale German protected areas, the Nationale Naturlandschaften e.V. (Flusslandschaft Elbe 2018). For certification, a contract between the BR management and the partner company, in which the rights and obligations of the contractual partners are defined, is mandatory. This is intended to support an important objective of a BR (as well as to support interested companies in the region) - namely to safeguard and to further develop local ways of life and economic activity, in a manner that is permanently environmentally compatible, and the infrastructure required for this, including the social and cultural foundations.

\section{Regional branding}

During an international MAB workshop on Biosphere Reserve Branding Through High Quality Products and Gastronomy, it was emphasized that branding and labelling of high-quality food products and gastronomy in BRs should play an essential role in the implementation of the Lima Action Plan 2016-2025 for the MAB Programme and its World Network of Biosphere Reserves, notably for reaching the desired outputs of actions C7.1 Global BR brand established with associated national guidelines, and C7.2 BR brand used in marketing of goods and services in line with national guidelines (MAB 2016).

The creation of a regional brand would certainly be a milestone for a BR in increasing the added value of a region. An excellent example of successful brand development is the Echt Entlebuch brand owned by the Association of Muncipalities within the Entlebuch BR. This seal of quality is awarded to specialities that are produced in the BR in accordance with strict guidelines, thus offering consumers the guarantee of a high-quality regional product. Products bearing the label are sold both inside and outside the Entlebuch $\mathrm{BR}$ to customers who are prepared to pay a higher price for innovative products of known origin and / or quality. In the BR itself, this strategy not only leads to additional sales volumes and thus to higher added value and the preservation of jobs, but also stimulates innovative product development (Ketterer Bonnelame et al. 2019). The brand, under which more than 500 products are now certified, thus serves as a successful culinary ambassador far beyond the BR's borders (Biosphäre Entlebuch 2020), generating more than six million euros in added value (Knaus 2012; Knaus et al. 2017; Ketterer Bonnelame et al. 2019). However, the development of a successful brand label is timeconsuming, requiring a participatory bottom-up process involving the largest possible number of people and companies; it also requires trust and constructive cooperation between the BR's management and producers (Ketterer Bonnelame et al. 2019).

Of the four Austrian BRs, only two (GWBR, and Nockberge [part of the SL\&KNBR]) have so far created their own brand labels for products that comply with quality criteria.

Unfortunately, creating business partnerships and the marketing of $\mathrm{BR}$ products are confronted by a major hurdle set up by UNESCO itself, namely the extremely restrictive guidelines on the use of UNESCO's own name, acronym and logos. Accordingly, neither the UNESCO logo (the well-known Temple) nor the official BR logo (composed of the UNESCO logo and the logo of the MAB programme) may be used for commercial purposes. This includes all forms of advertising, the sale of goods and services, merchandising, and commercial publications distributed through bookshops. Violation of this counter-productive rule may result in legal action being taken by UNESCO. As a result, BRs have not yet been able to use the world-famous UNESCO logo to advertise their high-quality products or to award to partner enterprises. The International Co-ordinating Council of the MAB programme has been trying to find a solution to this problem for many years through working groups and workshops.

\section{Product marketing}

While locals of course know where they can get local produce, it is usually much more difficult for tourists to find out where they can buy local foodstuffs. This is where the BR's management could provide support in the form of attractive informational material. It would certainly be an incentive for guests if accommodation businesses or restaurants offered a range of regional or even home-made products. In addition, the BR visitor centre (if there is one) or the local tourist office could offer a range of regional products for sale. In Austria, the visitor centre of the BRGW is a positive example in this respect: here, a BR Bistro offers high-quality local BR products and products from two other Austrian BRs (BRGW 2018b). Creating a year-round BR visitor centre, which is mentioned as a target criterion in the Criteria for BRs in Austria (MAB-Austria 2016) drawn up by the Austrian National Committee for the UNESCO MAB programme, would certainly be attractive for residents and visitors to the region alike if it also functioned as a sales outlet for regional products. 
As a study carried out in German BRs shows, many companies see a need for support through the BR's management, particularly in the areas of advertising and public relations (Kullmann 2007) - functions which could be fulfilled by year-round visitor centres.

From the perspective of environmental protection, logistics for the distribution of products represents a major challenge. Numerous studies show that transport routes are less significant in terms of impacts on climate-change than inefficient production and processing structures (Ermann et al. 2018). Shorter transport routes do not necessarily result in a smaller carbon footprint: for example, the $\mathrm{CO}_{2}$ efficiency of vehicles used for direct marketing is considerably lower than that of larger container ships. Thus, goods produced locally in glasshouses are not necessarily better than imported goods in terms of climate protection. Moreover, for ecological as well as economic reasons, it usually makes little sense to use motor vehicles for the delivery of individual products in the course of direct marketing. New online platforms with regional distribution points could help here in the future. The Austrian food platform Markta is a kind of digital farmers' market that links producers and consumers (Markta 2018). Here, producers can make their products visible and market them in a self-determined manner, at fair prices. High-quality and traceable manufactured goods are offered by regional micro-producers, about whom consumers also receive comprehensive information. The products are delivered directly from the farm, either individually or in a so-called combined shipment. Local suppliers and cooperatives serve as regional collection and dispatch points, and bundle orders from several producers at one location for combined dispatch or collection on site. This reduces distribution costs and carbon emissions.

In summary, given the fast and well-functioning logisitics systems already in place, the exchange of products between BRs could certainly be expanded with ease. Here too, an active BR management could not only contribute to the development of distribution networks, but also serve a central function for regional marketing. A German study shows that BR administrations have a key role to play in this respect (Kullmann 2005): after initial joint activities, the economic actors of a region expect the BR's management to take a leading role with regard to sustainability and the marketing of quality, as well as to provide continuity in terms of qualified and committed BR staff as key contacts.

Studies show that the culinary factor can play a decisive role in many types of holiday (Stöckl 2015, 2017). While alone the culinary offer is not usually a reason for choosing a destination, a non-existent offer, or one that is difficult for travellers to research, may be a reason to exclude a destination. For this reason, too, increased cooperation between the BR management, tourism associations, gastronomy and producers would be helpful.
With regard to the presentation and authenticity of its regional products, Italy can certainly serve as a role model. In the famous folk festivals known as Sagre, which attract large numbers of people, local products and specialities are put in the spotlight. While in the past these historic festivals usually had a religious character, many similar events have come into being in recent years with the aim of promoting regional gastronomic specialities.

UPVIVIUM, initiated by the Italian MAB National Committee in 2017, can be seen as an exemplary project that combines many aspects discussed in this article. This initiative is a gastronomic competition that brings together producers and food-lovers. The idea behind it is that BRs not only offer high-quality farm produce, but that their production techniques are also closely linked to the protection of the landscape and the environment. UPVIVIUM is a network of five Italian BRs, which are very diverse in terms of landscape and culture, but share a common vision: outstanding cuisine, with an emphasis on products guaranteed to be local (zero $\mathrm{km}$ - zero foodmiles), and the protection of local varieties / races and cultural biodiversity (UPVIVIUM 2019). The success of the project, which recognizes the important role of gastronomy as a vehicle for promoting the values of BRs and their underlying concept, is confirmed by the number of participants: in 2018 / 2019, which focused on the theme of bread, over 100 producers and 35 restaurants took part (Lenzerini 2019).

In the Austrian BRs, the promotion of authentic regional products by means of special events, which reach far beyond the borders of the BRs themselves, could certainly be expanded.

\section{Partnerships between farmers and cooks}

Committed gastronomic businesses can help to achieve the desired regionality of products by encouraging local producers, building their confidence and educating them. An outstanding example of this strategy, which unfortunately does not come from a BR region, is that of the renowned and multiple awardwinning South Tyrolean chef Norbert Niederkofler. Almost 10 years ago, he radically regionalized the cuisine of his Restaurant St. Hubertus in Alta Badia (South Tyrol, Italy), which until then had been based on international ingredients (Burghardt 2013). This change became possible only through years of persistent persuasion and motivation work among local producers. According to Niederkofler, it is important not only to confirm for farmers how important their work is, but also to give them purchase guarantees and to pay prices for their products that reflect the value of their work. Niederkofler also initiated the Cook the Mountain project presented at EXPO 2015 in Milan. The project, on mountain gastronomy, includes research workshops and events aimed at introducing the public to mountain cuisine and culture. The project is constructing a network of chefs, farmers, breeders, 
alpinists, naturalists, sociologists and businesses from mountain regions worldwide. In addition, Niederkofler is committed to ethical responsibility and sustainability in the gastronomy business with his CARE's project (the Ethical Chef days). This involves the responsible use of natural resources, appreciation of the work of producers and farmers, waste avoidance and recycling of leftovers (Niederkofler 2018).

Best practice examples of restaurants that have established successful partner networks with producers can, of course, also be found in Austria - for example, the Reitbauer family with the Steirereck and Wirtshaus Pogusch restaurants, Andreas Döllerer from Döllerers Genießerrestaurant in Golling, or Josef Floh of Gastwirtschaft Floh in Langenlebarn. The chef of Gastwirtschaft Floh obtains almost all the produce used in the kitchen from within a radius of around $66 \mathrm{~km}$ of the restaurant. Diners in these restaurants will certainly appreciate that a good proportion of the vegetables on their plates comes from farmers 'just around the corner', instead of being transported over long distances by plane or truck.

All initiatives have one thing in common: they establish and showcase local producers as important partners of the local gastronomy, highlighting the special features of regionality and sustainability, and thus contributing to the continued existence of the products and to the economic survival of the producers.

Although BRs as model regions for sustainable development would be ideal for such cooperation, successful networks between chefs and producers seem to be under-represented in Austria's BRs.

\section{Cookbooks}

Regional cuisine is not only an important element of cultural identity; it also contributes to the sustainable economic development of a region by increasing the demand for, and consumption of, local produce. A cookbook presenting the beauty and uniqueness of a region and its culinary products in an attractive way, allowing producers and chefs alike to express the meaning and benefits of their work, as well as explaining the possible benefits of enjoying local products on the region, can be an ideal instrument for helping public understanding of the complex interrelationships between an often centuries-old cultural landscape and the products created from it, and the need to protect the region and its biodiversity through the sustainable use of its resources. Furthermore, a welldesigned cookbook, even if specifically tailored to a $\mathrm{BR}$, can also reach far beyond the boundaries of the BR. Indeed, in recent years, some BR managers have recognized the suitability of cookbooks as vehicles for promoting the complex concept of BRs as model regions for sustainable development.

Ten years ago, the Austria's national MAB Committee successfully used the culinary enjoyment potential of the country's BRs to bring the modern but rather abstract concept of the UNESCO BRs closer to the public by means of a publicity campaign centred on a cookbook. The project, Vielfalt Genießen (Enjoying Diversity), was conceived as a three-stage programme. It started with a competition for schools during the International Year of Biodiversity 2010, followed by the publication of an award-winning cookery book, The Austrian Biosphere Reserves. A Connoisseur's World, and culminated in an educational programme about BRs, lasting more than a year, carried out at the Landesberufsschule Waldegg (a vocational college for the hotel and catering trades). This third stage of the project was complemented by BR-related activities (recipes using ingredients from the BRs; an information folder) in selected restaurants around the Wienerwald BR (Köck et al. 2011, 2013; Köck 2019).

Additional examples from Austria are the two cookbooks from the Grosses Walsertal BR (BRGW 2006, 2015). Further successful examples come from elsewhere in Europe: cookbooks from Schorfheide Chorin and Berchtesgaden BRs in Germany; a cookbook about the Dordogne BR in France; from Spain, a cookbook from the Gran Canaria BR, and one published by the Spanish Ministry of Agriculture, Fisheries, Food and Environment, with recipes from all 48 Spanish BRs (Stäblein 2009; Lenz 2014; Amir 2016; CdGC 2018; Ministerio 2018).

Meanwhile, the key roles of high-quality produce and gastronomy in BRs have also been recognized by the wider MAB Community. For example, an international MAB workshop on Biosphere Reserve Branding Through High Quality Products and Gastronomy recommended that the MAB programme should produce a cookbook that includes recipes from BRs around the world (MAB 2016).

\section{The culinary enjoyment potential of Aus- trian BRs}

A long-standing priority of the Austrian MAB Committee and BR managments has been and still is to significantly increase the level of popularity of Austria's BRs. The topic of culinary enjoyment is certainly a successful advertising strategy to get both the local populations and visitors interested in BRs.

The Austrian BRs have also recognized this, launching initiatives for the production and marketing of regional products. The introduction in 2005 of the Genuss Region Österreich brand, an umbrella brand of the Austrian Ministry for Agriculture, Regions and Tourism and Agrarmarkt Austria (AMA), was helpful in this context (Genuss Region 2019). The aim of this initiative was to make visible the regional origin and production methods of farm produce and specialities while also providing information about the culinary offers of the individual regions. Each region has a lead product, which the region has created and markets itself and which, if possible, has a close connection to the traditional cultural landscape of the area. In order 
to take account of the growing trend towards regionality and consumers' desire to know where their food comes from and how it is produced, the brand, which is very well known in Austria, was realigned in 2020 within the framework of the Culinary Austria strategy with the introduction of the new seal of quality $A M A$ Genuss Region and the founding of the Netzwerk. Kulinarik (Culinary Network). The initiative also includes continuous monitoring of the quality and origins of products (Netzwerk Kulinarik 2020). The label can be used by certified, rural, direct marketers, producers and gastronomy businesses. This is intended to lay the foundation for stronger networking and synergies between all businesses involved in the value-added chain. The next step is to establish a joint sales and marketing strategy. An additional component of the initiative is the database of Traditional Foods in Austria, which aims to collect, make public and preserve traditional knowledge about Austria's culinary heritage. It contains details of produce and dishes that have been cultivated or made using traditional knowledge in Austria for at least 3 generations or 75 years (BMLRT 2015). Among the more than 100 Austrian regions of culinary enjoyment, seven belong to BRs: Großwalsertaler Bergkëse Walserstoly (mountain cheese), Lungauer Eachtling (potatoes), Nockberge Almrind (a breed of cattle that spends the summer grazing on mountain pastures), Wiesenwienerwald Elsbeere (wild service tree), Steirische Käferbohne (Styrian scarlet runner bean), Steirischer Kren (Styrian horseradish) and Steirisches Kürbiskernöl (Styrian pumpkin seed oil). Four of these BR products are also protected by the PDO and PDI schemes (European Commission 2020c): Walserstolz mountain cheese known as Vorarlberger Bergkäse PDO, Styrian Scarlet Runner Bean PDO, Styrian Horseradish PGI, and Styrian Pumpkin Seed Oil PGI.

\section{Selected examples of culinary delights from Austrian biosphere reserves}

Here, due to limited space, we describe only products that are typical of the BR region, have a long tradition, and thus, to a certain extent, represent flagship products. A more complete list of typical BR products along with their detailed descriptions are presented as Supplementary Information (Table S1, available online).

\section{Grosses Walsertal BR (GWBR)}

One success story of this region is the founding of the Walserstolz cheese brand (Walserstolz 2018). Typical of the region are the many high-altitude alpine dairies, which are difficult to manage and have considerably higher production costs compared to their competitors. In the 1970s and 1980s, the situation was exacerbated by low milk prices, so there was a risk that many of these small farms would be abandoned. In 1998, Walserstolz created a common regional brand under which three alpine dairies produce high-quali- ty mountain cheese made from silage-free hay milk. The construction of a modern cooperative dairy in the village of Sonntag has greatly facilitated independent milk processing, with milk being bought at a reasonable price, and ensuring lower production costs and thus higher added value. The involvement of a larger company (Emmi Österreich $\mathrm{GmbH}$ ) increased the supra-regional sales opportunities, such that many products have been available throughout Austria for a number of years. This has also increased the level of awareness of the BR throughout Austria. As a result, both jobs and traditional agricultural practices have been preserved. Traditionally, the summer months in the high alpine pastures play a major role in mountain farming. In the GWBR, 47 such pastures are currently being farmed, and on 20 of these the milk is transformed into various products directly on site during the summer (Rumpold \& Klenovec 2019).

Another project is the herbal initiative Alchemilla, founded in 2006 by women who love and are knowledgeable about herbs, which aims to impart herbal knowledge and the special value of the region's plant diversity (BRGW 2018a). The members of the initiative offer seminars on local herbal knowledge that has been handed down over centuries, and convey the sensitive interactions between man and nature during herbal walks. The women also produce high-quality handcrafted products made from local herbs and raw materials, including body-care products and culinary delicacies such as herbal tea, herbal syrups and wild herbal salt.

The local added value creates jobs in the region and thus secures the living space for future generations. Furthermore, the use of regional crops also contributes to the preservation of traditional food, drinks and customs, which in turn encourage production of the traditional crops. The transfer of traditional knowledge of wild plants in natural areas, cultivated plants and agriculture is thus ensured.

\section{Salzburger Lungau \& Kärntner Nockberge BR (SL\&KNBR)}

A success story from the Salzburg part of the SL\&KNBR is the conservation of Lungauer Tauern Rye, a heritage cereal that was typical of the region. This variety is well adapted to the harsh climatic conditions of the Lungau region and very well suited for cultivation in the marginal areas of grain cultivation due to its undemanding nature. Until the 1960s, Lungauer Tauern Rye was the most important cereal variety in the Upper Enns Valley (BMLRT 2017a). By the middle of the 20th century, the original seed was being propagated and marketed by more than 100 mountain farms in the Lungau. In 1954, the distribution of Tauern Rye reached its peak, with 122 hectares under cultivation; in 2005, the rye accounted for only about 2 hectares (Kulinarisches Erbe 2018). However, a Slow Food initiative launched in 2006, which led to the creation of the Lungauer Arche Association, 
has quadrupled the area of Tauern rye, certified by the Austrian Food Safety Agency as now covering 8 hectares (Löcker 2020 pers. comm.). The cultivation of this variety makes an important contribution to the preservation of ecological diversity, the enrichment of the cultural landscape, and the development of a typical regional food culture.

The management of the Salzburg part of the BR is committed to creating infrastructure for the production of regional products by means of a participatory regional agenda. Among other things, this promotes the labelling, marketing and purchase of local quality products in order to preserve small-scale, traditional agriculture in the region (BRSL\&KN 2018a).

The Carinthian part of the BR also offers great gastronomic potential. A few years ago, the BR's management, together with regional producers, reviewed potential BR products according to quality criteria and awarded them a label. These range from Nockberge alpine cattle, honey, fish and cheese, to alpine hay products (BRSL\&KN 2018b).

The region has a centuries-old tradition of extensive livestock farming on the mountain pastures, which are located at between 1500 and 2440 metres a.s.l. The high quality of the meat of the Nockberge Almrind cattle is the result of the cattle being raised outdoors, including the obligatory summer grazing on the alpine pastures in the Nockberge area. The grazing of the alpine pastures up to the summit areas is a special feature of the region. The environmentally conscious and soil-conserving management of the farms and alpine pastures contributes significantly to the sustainable maintenance of the alpine landscape in the region.

The BR's management is strongly commited to supporting the producers in marketing their high-quality products and has recently created an online marketing platform for produce from the Nockberge region (Mayer 2021 pers.comm.). This creates and maintains jobs in the region, while the producers also do very valuable work for the preservation of the unique landscape and high biodiversity of the Nockberge.

\section{Wienerwald BR (WBR)}

A few years ago, the BR's management started to create a network of producing, processing and marketing companies in the fields of agriculture, gastronomy and accommodation, and to draw up criteria for membership. The Biosphärenpark Wienerwald Partnerbetrieb award is given to companies that live the philosophy of the BR (namely ecological, social and economic sustainability), and are committed to increased cooperation with the WBR and the surrounding area (BRWW 2020a).

The BR, founded in 2005, currently has a small partner network relative to its size and age, despite the fact that the BR includes a large number of producers and thus potential partner companies. One reason for the under-utilization of the region's great potential could be that the BR has failed to convey to businesses the added value of being awarded the status of a partner enterprise. As the companies are located in the wealthy suburban sprawl of Vienna (a city with almost two million inhabitants), and can therefore easily sell their products, it could be that they do not see any additional advantage from belonging to such a network. A further reason could be that the criteria are too narrowly defined, which overtaxes the possibilities of the companies. Recently, however, new initiatives have been undertaken by the new management to expand the partner network. Since spring 2020, for example, a blog created by the BR's management on the subject of Sustainable consumption in the region presents producers and their gourmet products from the BR.

The Wienerwald is not only an exceptional forest area, but also has a share in three outstanding wine regions. These species-rich viticultural landscapes were one of the reasons for the designation of the area as a UNESCO BR. A special feature is the traditional Wiener Gemischter Satz wine, listed as a Slow Food Presidium since 2008. In February 2020, an application was submitted for this wine to be included in the EU register of Protected Designations of Origin PDO (European Commission 2020c).

Since 2006, certificates and special labels have been awarded by the BR's management for the best wines produced in the BR. In order to promote sustainable viticulture in the WBR, only wines that have been cultivated and produced within the BR in an ecologically sustainable manner are eligible to compete (BRWW 2020b). Each award-winning winery is assigned a special animal or plant species found in its vineyards, which it protects and preserves in the form of a sponsorship through the sustainable cultivation of its vines. The responsible and sustainable management of the vineyards forms the basis for an intact cultural landscape and ensures its extraordinary biodiversity. By purchasing these wines, the consumer can therefore not only enjoy excellent wines, but also contribute to the preservation of the unique viticultural landscape and high biodiversity in the BR.

Unfortunately, the WBR Wine Award is overshadowed by several well-known and thus very influential wine awards made by gastronomy journals and wine fairs, awards which are of great importance for the winemakers in terms of consumer visibility and the marketing of their products. Thus the winemakers in the $\mathrm{BR}$ promote the awards for BR wines only to a small extent, and so their public impact is comparatively low.

\section{Lower Mura Valley BR (UMBR)}

As the BR located in south-eastern Styria was officially recognized only in June 2019, it is too early to list any BR-specific activities. However, as the area belongs to the Steirisches Vulkanland region, which comprises 32 municipalities, the potential for culinary enjoyment here is very high. Within the framework of its Vision 
2025 created in 2010 and presented in the nomination application to UNESCO, the Steirisches Vulkanland brand, which has existed since 1999, is committed to shaping the three areas regional life culture, living space and egional economy, with the involvement of local people, in such a way that the region will continue to maintain its human, ecological and economic foundations for independent development and high quality of life (Steirisches Vulkanland 2019).

The Mur river plane in southeast Styria offers not only great nature experiences in Austria's second largest alluvial forest, but also a wealth of excellent regional culinary delights and products - on both sides of the state border between Austria and Slovenia, which is formed by the Mur. Under the umbrella of the GlaMUR Genuss am Fluss (Culinary Enjoyment along the River Mur), a transboundary network of more than 200 Austrian and Slovenian businesses from ten Austrian and nine Slovenian municipalities has been formed to draw attention to the immense diversity of regional culinary products in the lower Mur valley. The network includes high-quality businesses such as inns, wine taverns (Buschenschenken), fruit and vegetable producers, farm shops with regional products, innovative winemakers and breweries (GlaMUR 2020). GlaMUR combines the region's wide range of tourism offers with the finest culinary delights and regional produce. In addition, through various measures such as cooperation with schools, it aims to convince people to shop and consume regionally.

Three flagship products of the south-east Styrian region, which have almost cult status, are the Styrian Scarlet Runner Bean PDO, Styrian Pumpkin Seed Oil PGI, and Styrian Horseradish PGI (BMLRT 2017 b,c,d). Styrian Pumpkin Seed Oil PGI especially is iconic and inseparable from the culinary culture of Styria (see Table S1). Like many other high-priced food products, the oil is frequently a victim of counterfeiting: seeds from other regions (e. g. China) are pressed along with the Styrian pumpkin seed, or oils of different kinds and origins are mixed. However, there are reliable test methods to detect such fakes, for example elemental fingerprinting, developed by the University of Leoben to determine the precise geographical origin of the oil (Bandoniene et al. 2013).

More recently, two promising BR initiatives with culinary potential have emerged, namely rice cultivation using the dry rice cultivation method, and historical and traditional cross-border wine production (Fröhlich 2020; Fuchs 2020; Weinzeitung 2020; G. Pock 2020 pers.comm; see also Table S1).

With the new transboundary 5-Country Biosphere Reserve Mura-Drava-Danube (TBR MDD), connecting Austria, Croatia, Hungary, Serbia and Slovenia with their individual BRs, further positive, sustainable, development of the regional economy can be expected through greater cross-border cooperation (Köck et al. 2022).

\section{Conclusion}

Culinary products can be valuable in terms of how people identify with their region. Local people are often proud of high-quality regional products. In addition, the producers can feel that they are an active part of the BR as a model region for sustainable living and economic activity. In this way, traditional practices can be not only safeguarded, but also further developed to meet future needs.

As the success of the Austrian BR cookery book shows, the Austrian BRs are already using the existing culinary potential quite successfully. However, there is room for expansion in the partner networks, through partnerships between producers and the gastronomic sector, as well as by the introduction of a regional or even nation-wide BR brand.

The maintenance and/or increase of agrobiodiversity and the protection of sustainable traditional agriculture should be important roles for BRs. To this end, agriculture should be positioned more strongly as a strategic partner of tourism, trade and gastronomy. Functioning networks between local producers and catering businesses - including, of course, the food trade - are certainly an excellent basis for supporting the regional economy. If restaurateurs increasingly purchased their products direct from farmers and regional suppliers, it would be worthwhile for agriculture to focus more on the needs of chefs, for example by planting old and heritage varieties of fruit and vegetables. Such cooperation would thus help keep alive fruit and vegetable varieties that are suitable for the region but can barely cope with market pressure, and whose disappearance would change the character of the cultural landscape. Although many old varieties are less productive than the few mass-produced varieties available in supermarkets, they usually taste much better - a fact that creative chefs take advantage of in order to continue using traditional recipes or to create refined or new recipes from old varieties.

In summary, restaurants that use local produce for their dishes are an excellent and very visible stage for presenting a region and its cultural landscape, even though there will and should continue to be chefs who bring the tastes of the world closer to their guests, using products from other more distant parts of the world (e. g. sea fish instead of fish from lakes or local fish farming, exotic spices instead of regional herbs). However, despite curiosity and interest in exotic products and tastes, there will be an increasing number of diners, especially in times of climate change, who are concerned to keep their ecological footprint small, and to contribute to the protection of the environment and thus society by preferring to enjoy high-quality local produce with low food miles.

It is not only local actors in the food supply chain, including restaurants and consumers, who should be held accountable. In many of the activities described above, an active BR management could be both ini- 
tiator and hub to collect, develop and disseminate ideas appropriately. In addition, through educational programmes and the provision of information, a BR's management can raise awareness concerning the importance of preserving the cultural landscape, agrobiodiversity, and the advantage of local economic cycles, thus sowing the seeds for new ideas and futureoriented concepts. In addition, the national committees could become more involved in communications with the general public as well as with potential BR partners, and in generating or uncovering new ideas to foster sustainable development within the BRs. Last but not least, UNESCO itself and the national committees should pause to think. UNESCO should allow BRs to use its logo for labelling BR products and identifying partner businesses.

\section{Acknowledgements}

I would like to thank Valerie Braun (ÖAW-IGF Institute for Interdisciplinary Mountain Research, Innsbruck), Renate Eder, Marianne Penker and Christian R. Vogl (all at the University of Natural Resouces and Life Sciences, Vienna), Heinz Mayer (SL\&KNBR), Andreas Breuss (UMBR) and Georg Pock for a critical reading of the manuscript and their helpful comments. I am indebted to Kati Heinrich (ÖAW-IGF) for the creation of the BR map. Special thanks are due to Mary Rigby for the time-consuming English editing of this text, which contains many specifically Austrian terms.

\section{References}

Alpfoodway 2019. Alpfoodway. Available at: https:// www.alpinespace.eu/projects/alpfoodway/en/home (accessed: 15/06/2020).

Amir, M. 2016. Saveurs de paysages: au fil de la Dordogne. Plume Carotte. Toulouse, France.

Asamer-Handler, M. \& F. Handler 2019. Kulinarische regionale Produkte in europäischen Naturparken - ein Überblick. In: Mose, I. \& N. Weixlbaumer (eds.), Geografien des Essens - Perzeption und Rezeption von Schutzgebieten im Spiegel kulinarischer regionaler Produkte: 23-46.

Bandoniene, D., D. Zettl, T. Meisel \& M. Maneiko 2013. Suitability of elemental fingerprinting for assessing the geographic origin of pumpkin (Cucurbita pepo var. styriaca) seed oil. Food Chemistry 136(3-4): 1533-1542.

BfN (Deutsches Bundesamt für Naturschutz) 2020. Agrarbiodiversität. Available at: https://www.bfn. $\mathrm{de} /$ themen/landwirtschaft/agrarbiodiversitaet.html (accessed: 15/06/2020)

Biosphäre Entlebuch 2020. UNESCO Biosphäre Entlebuch. Available at: https://www.biosphaere.ch/de/ unesco-biosphaere-a-z/regionalprodukte/die-markeecht-entlebuch/ (accessed: 15/06/2020)
BMLRT (Bundesministerium für Landwirtschaft, Regionen und Tourismus) 2015. Traditionelle Lebensmittel in Österreich. Available at: https://www.bmlrt.gv.at/ land/lebensmittel/trad-lebensmittel/tlm_in_oe.html (accessed: 03/06/2020)

BMLRT 2017a. Lungauer Tauernroggen. Available at: https://www.bmlrt.gv.at/land/lebensmittel/tradlebensmittel/spezialkulturen/lungau_tauernroggen. html (accessed: 03/06/2020)

BMLRT 2017b. Steirische Käferbohne g.U. Available at: https://www.bmlrt.gv.at/land/lebensmittel/tradlebensmittel/spezialkulturen/steir_kaeferbohne.html (accessed: 16/06/2020)

BMLRT 2017c. Steirisches Kürbiskernölg.g.A. Available at: https://www.bmlrt.gv.at/land/lebensmittel/tradlebensmittel/oel/steir_kuerbiskernoel.html (accessed: 16/06/2020)

BMLRT 2017d. Steirischer Kren g.g.A. Available at: https://www.bmlrt.gv.at/land/lebensmittel/trad-lebensmittel/spezialkulturen/steirischer_kren.html (accessed: 16/06/2020)

BRGW (Biosphärenpark Großes Walsertal) 2006. Ein Genuss, so schmecket's im Biosphärenpark Großes Walsertal. Biosphärenpark Management der REGIO Großes Walsertal (ed.).

BRGW 2015. Biosphärenpark Kochbuch - wilde Kräuterküche. Biosphärenpark Management der REGIO Großes Walsertal (Hrsg.).

BRGW 2018a. Biosphärenpark Großes Wassertal: Alchemilla. Available at: http://www.grosseswalsertal.at/ alchemilla/ (accessed: 17/06/2020).

BRGW 2018b. Biosphärenpark Großes Walsertal: Biosphärenpark-Bistro. Available at: https:/ /www.grosseswalsertal.at/biosphaerenpark_haus/biosphaerenpark_ bistro (accessed: 03/06/2020)

BRSL\&KN (Biosphärenpark Salzburger Lungau \& Kärtner Nockberge) 2018a. Wir sind Biosphäre - Das Magazin. Tätigkeitsbericht 2016/2017. Salzburger Teil des Biosphärenparks „Salzburger Lungau und Kärntner Nockberge“, Mauterndorf (Salzburg).

BRSL\&KN 2018b. Regionales aus dem Biosphärenpark Nockberge. Available at: https://www.biosphaerenparknockberge.com/service/folder/ (accessed: 03/06/2020).

BRWW (Biosphärenpark Wienerwald) 2020a. Biosphärenpark Wienerwald. Available at: https:// www.bpww.at/de/themenseiten/partner (accessed: 03/06/2020).

BRWW 2020b. Biosphärenpark Wienerwald - Der Wein. Available at: https://www.bpww.at/de/ aktivitaeten/biosphaerenpark-wienerwald-der-wein (accessed: 27/04/2020)

Burghardt, A. 2013. Der Rattenschwanz des Radius. A la carte 2013/3.

CdGC 2018. Recetas de la Reserva de la Biosfera de la Gran Canaria. Cabildo de Gran Canaria. Available at: http://descargas.grancanaria.com/medio_ambiente/ reserva\%20biosfera/recetas/fichas-recetas-biosferagcweb.pdf (accessed: 27/04/2020) 
Ermann, U., E. Langthaler, M. Penker \& M. Schermer 2018. Agro-Food Studies. Eine Einführung. ITB-Band 4830.

EU-IPR Helpdesk 2016. Fact Sheet: The value of geographical indications for businesses. Available at: https://www.iprhelpdesk.eu/sites/default/ files/newsdocuments/Fact-Sheet Geographical_ Indications_0.pdf (accessed: 21/07/2020)

European Commission 2020a. A Farm to Fork Strategy for a fair, healthy and environmentally-friendly food system. Available at: https:/ /eur-lex.europa.eu/legal-content/ EN/TXT/?uri=CELEX:52020DC0381 (accessed: 27/04/2020)

European Commission 2020b. EU Biodiversity Strategy for 2030 - Bringing nature back into our lives. Available at: https://ec.europa.eu/info/sites/info/files/ communication-annex-eu-biodiversity-strategy-2030_ en.pdf (accessed: 27/04/2020)

European Commission 2020c. eAmbrosia - the EU geographical indications register. Available at: https:// ec.europa.eu/info/food-farming-fisheries/foodsafety-and-quality/certification/quality-labels / geographical-indications-register/ (accessed: $27 / 09 / 2020)$

FAO 2020. Globally Important Agricultural Heritage Systems (GLAHS) Programme. Food and Agricultural Organization of the United Nations. Available at: http:// www.fao.org/giahs/en/ (accessed: 27/04/2020)

Flusslandschaft Elbe 2018. Partnerbetriebe. Available at: http://www.flusslandschaft-elbe.de/ partnerbetriebe/ (accessed: 27/04/2020)

Fröhlich E. 2020. So-Fröblich-Reis. Available at: https://so-froehlich.at/ (accessed: 10/10/2020)

Fuchs 2020. SteirerReis by Fuchs. Available at: https://www.steirischerreis.at/ (accessed: 27/10/2020)

G20 2018. Declaration G20. Meeting of Agriculture Ministers, 27-28 July2018, Buenos Aires, Argentina. Available at: https://www.bmel.de/SharedDocs/ Downloads/DE/_Internationales/GFFA/G20_Erklaerung_2018.pdf?_blob=publicationFile\&v $=3$ (accessed: 27/04/2020)

Genuss Region 2019. Genuss Region. Available at: https://www.genussregionen.at/ (accessed: $17 / 06 / 2020)$

GlaMUR 2020. GlaMUR - Genuss am Fluss. Available at: http://www.genussamfluss.at/ (accessed: 22/07/2020)

IPBES 2019. Policy Platform on Biodiversity and Ecosystem Services. S. Díaz, J. Settele, E. S. Brondízio E.S., H. T. Ngo, M. Guèze, J. Agard, A. Arneth, P. Balvanera, K. A. Brauman, S. H. M. Butchart, K. M. A. Chan, L. A. Garibaldi, K. Ichii, J. Liu, S. M. Subramanian, G. F. Midgley, P. Miloslavich, Z. Molnár, D. Obura, A. Pfaff, S. Polasky, A. Purvis, J. Razzaque, B. Reyers, R. Roy Chowdhury, Y. J. Shin, I. J. Visseren-Hamakers, K. J. Willis, and C. N. Zayas (eds.). Bonn, Germany.

Ketterer Bonnelame, L., F. Knaus \& D. Siegrist 2019. Der Biosphäreneffekt von regionalen Label Produkten in der UNESCO Biosphäre Entlebuch. In:
Mose, I. \& N. Weixlbaumer (eds.), Geografie des Essens - Perzeption und Rezeption von Schutzgebieten im Spiegel kulinarischer regionaler Produkte: 117-137.

Knaus F. 2012. Bedeutung, Charakteristiken und wirtschaftliche Auswirkungen des Sommertourismus in der UNESCO Biosphäre Entlebuch. Resultate einer umfassenden Gästebefragung. Interner Bericht, ETH Zürich und Biosphärenmanagement UBE, Schüpfheim.

Knaus F., L. Ketterer Bonnelame \& D. Siegrist 2017. The Economic Impact of Labeled Regional Products: The Experience of the UNESCO Biosphere Reserve Entlebuch. Mountain Research and Development 37(1): 121-130.

Köck, G. 2019. Vielfalt genießen - Die österreichischen Biosphärenparks als Modellregionen für regionalen Genuss. In: Mose, I. \& N. Weixlbaumer (eds.), Geografie des Essens - Perzeption und Rezeption von Schutzgebieten im Spiegel kulinarischer regionaler Produkte: 139-181.

Köck, G., L. Lammerhuber \& M. Umhack 2011. Vielfalt Genießen - Das Kochbuch der österreichischen Biosphärenparks (A Connoisseur's World - The Austrian Biosphere Reserves).

Köck, G., G. Schwach \& A. Mohl 2022. MuraDrava-Danube Biosphere Reserve: A long way from the original idea to the designation of the world's first 5-Country Biosphere Reserve. International Journal of Development and Sustainability (in press).

Köck, G., M. Umhack \& C. Diry 2013. The Austrian Biosphere Reserves- A (connoisseurs's) world beyond the cookery book. eco.mont - Journal on protected mountain areas research and management 5(2): 59-63.

Kraus, F. 2015. Nachbaltige Regionalentwicklung im Biosphärenreservat Rhön. Regionale Wertschöpfungsketten diskutiert am Beispiel der Dachmarke Rbön. Würzburger Geographische Arbeiten 114.

Kulinarisches Erbe 2018. Kulinarisches Erbe Österreichs. Available at: https://www.kulinarisches-erbe. at/kulinarik-mit-tradition/pflanzen/getreide-getreidealternativen/lungauer-tauernroggen/ (accessed: 27/04/2020)

Kullmann, A. 2005. Status-Quo der Regionalvermarktung in den deutschen Biosphärenreservaten. Beiträge Region und Nachhaltigkeit, II. Überregionale Forschungsberichte mit MAB-Bezug: 48-61.

Kullmann, A. 2007. Regionalvermarktung in den deutschen Biosphärenreservaten - Status Quo-Analyse und Optimierungspotentiale. BfN-Skripten 175.

Lenz, T. 2014. Das Kochbuch Schorfheide Chorin: Leckereien aus dem Biosphärenreservat.

Lenzerini, F. 2019. Gastronomic contest at km 0 between Italian biosphere reserves. Presented at the Workshop „Role of biospheres when engaging with local enterprises (business charters \& branding/ regional product labelling): Opportunities to implement the 'Development' goal of Biospheres ". EuroMAB Conferene „Local Actions for Global Challenges“, 2-5 April 2019, Dublin (Ireland).

MAB 2016. MAB International Workshop „Biosphere Reserve Branding Through High Quality Products and Gastronomy": Draft Summary Conclusions, Recommendations and 
Next Steps. 30 August-1 September 2016, Langharino (Italy). Available at: http://www.mabappennino.it/pdf/ MAB.Worksho.P.Dogse.pdf (accessed: 27/04/2020)

MAB-Austria 2016. Criteria for Biosphere Reserves in Austria. Available at: http://www.biosphaerenparks. at/images/pdf/CriteriaAustrianBR_2016_eng.pdf (accessed: 27/04/2020)

Markta 2018. Markta - Der digitale Bauernmark.t. Available at: https://markta.at/ (accessed: 27/04/2020)

Ministerio 2018. Recetas Reserva de la Biosfera, Ministerio de Agricultura, Pesca, Alimentación y Medio Ambiente, Madrid (Spain). Available at: http:/ / rerb.oapn. es/images/PDF_publicaciones/LIBRO_RECETAS_ COMPLETO_WEB.pdf (accessed: 27/04/2020)

Netzwerk Kulinarik 2020. Netzwerk. Kulinarik. Available at: https://b2b.amainfo.at/kulinarik/ (accessed: 22/06/2020)

Niederkofler, N. 2018. Cook the Mountain. http:// www.n-n.it/de/ (accessed: 27/04/2020)

Rhön 2019. Biosphärenreservat Rhön. Available at: https://www.biosphaerenreservat-rhoen.de/unescobiosphaerenreservat/partner/partner-in-der-rhoen/ (accessed: 27/04/2020)

Rumpold, P.A. \& C. Klenovec 2019. Bergkäse aus dem Biosphärenpark Großes Walsertal - ein berglandwirtschaftliches Regionalprodukt in Perzeption und Praxis. In: Mose, I. \& N. Weixlbaumer (eds.), Geografie des Essens - Perzeption und Rezeption von Schutzgebieten im Spiegel kulinarischer regionaler Produk.te: 209-231.

Scheurer, T., M. Agnoletti, M. Bürgl, M. Smid Hribar \& M. Urbanc 2018. Exploring alpine landscapes as potential sites of the Globally Important Agricultural Heritage Systems (GIAHS) Programme. Mountain Research and Development 38(2): 172-174.

Slow Food 2018. Slow Food Foundation for Biodiversity. Available at: https://www.fondazioneslowfood.com/ en/ (accessed: 22/06/2020)

Stäblein, W. 2009. Das Regional-Kochbuch: Ois wia's wachst - Ein saisonales und regionales Kochbuch aus dem Biosphärenreservat Berchtesgaden. Berchtesgadener Anzeiger: 104.

Steirisches Vulkanland 2019. Steirisches Vulkanland. Available at: https://www.vulkanland.at/ (accessed: 27/04/2020)

Stöckl, A.F. 2015. Kostbares Österreich. IMC FH Krems.
Stöckl, A.F. 2017. Kostbares Österreich. Chancen für eine Regionalentwicklung in Niederösterreich. IMC FH Krems. Available at: https://www.google.com/ url? $\mathrm{sa}=\mathrm{t} \& \mathrm{rct}=\mathrm{j} \& \mathrm{q}=\& \mathrm{esrc}=\mathrm{s} \& \operatorname{source}=\mathrm{web} \& \mathrm{~cd}=1$ $\& \mathrm{cad}=$ rja\&uact $=8 \& v e d=2$ ahUKEwjDqNvy1_vc AhUKIJoKHdZgDEEQFjAAegQIAxAC\&url= https $\% 3 \mathrm{~A} \% 2 \mathrm{~F} \% 2 \mathrm{Fwww}$.waldviertel.at $\% 2 \mathrm{Faction}$ $\% 2$ Fdownload $\% 3$ Fid $\% 3 \mathrm{D} \% 257 \mathrm{Bbe} 484288-106 \mathrm{c}$ 5147-f38d-f1451f65574f\%257D\&usg=AOvVaw09rBEZDqfinDaRgzygaaet (accessed: 27/04/2020)

UPVIVIUM 2019. Biosfera gastronomica a km zero. Available at: https://www.upvivium.it/ (accessed: 27/04/2020)

Walserstolz 2018. Walserstolz - Die Vorarlberger Käsespezialität. Available at: http://www.walserstolz. at/ (accessed 27/04/2020)

Weinzeitung 2020. Weinzeitung ,wein.erlebnis". Available at: https://oberhollenzer.at/wp-content/ uploads/2020/08/Weinzeitung-A3_300720_ RZ_Einzelseiten_Ansicht_final.pdf (accessed: $21 / 10 / 2020)$

Weixlbaumer, N. \& I. Mose 2019. Geografien des Essens im Kontext von Schutzgebieten und regionalen kulinarischen Produkten. In: Mose, I. \& N. Weixlbaumer (eds.), Geografie des Essens - Perzeption und Rezeption von Schutagebieten im Spiegel kulinarischer regionaler Produkte: 7-22.

WIPO 2017. Geographical Indications: An Introduction. World Intellectual Property Organization, Geneva (Switzerland). Available at: https://www.wipo.int/edocs/pubdocs/en/geographical/952/wipo_pub_952.pdf (accessed: $21 / 07 / 2020)$

\section{Author}

\section{Günter Köck}

is Secretary-General of the Austrian MAB National Committee, former Vice-Chair of the UNESCO MAB Programme, and the Austrian delegate to the European Alliance of Global Change Research Committees, member of the Scientific Board of Hohe Tauern National Park, as well as one of the Austrian delegates to the International Scientific Committee for Alpine Research. In 2009 he became one of the founding editors of eco.mont. 